\title{
The Enhanced Effect of Bicarbonate Anion for the Removal of 2,4- Dichlorophenoxyacetic Acid on a Palladium/Nickel-Foam Electrode
}

\author{
Q X LIU', Q P TIAN ${ }^{\mathrm{b}}$, X Y YEa, F R LIU', H M YUAN ${ }^{\mathrm{a}}$ and C Y LOU ${ }^{\mathrm{a}, 1}$ \\ ${ }^{a}$ Zhejiang Light Industrial Product Inspection and Research Institute, Hangzhou \\ 310018, People's Republic of China \\ ${ }^{\mathrm{b}}$ Zhejiang Institute of Mechanical and Electrical Engineering Co., LTD., Hangzhou \\ 310051, People's Republic of China
}

\begin{abstract}
Palladium/nickel-foam (Pd/Ni) electrode is used as a typical efficient electrocatalytic electrode for the removal of 2,4-dichlorophenoxyacetic acid (2,4-D) in surface water and industrial wastewater. Many researches had reported how to enhance the dechlorination efficiency of the Pd/Ni electrode by using less Pd loading. However, there are few reports of choosing a suitable electrolyte solution to improve the efficiency of dechlorination. Efforts were made in this work of the different catholyte influenced the dechlorination efficiency. The results showed the fastest removal efficiency of 2,4-D in $34 \mathrm{mmol} / \mathrm{L} \mathrm{NaHCO}_{3}$ than in $34 \mathrm{mmol} / \mathrm{L} \mathrm{NaCl}, 34$ $\mathrm{mmol} / \mathrm{L} \mathrm{NaClO}_{4}, 17 \mathrm{mmol} / \mathrm{L} \mathrm{Na}_{2} \mathrm{SO}_{4}$ catholyte, respectively on $\mathrm{Pd} / \mathrm{Ni}$ electrode with pd loading of $0.202 \mathrm{mg} / \mathrm{cm}^{2}$ at constant potential of $-0.55 \mathrm{~V}$ (vs saturated calomel electrode). The dechlorination current efficiency (CE) was $20.5 \%$ in the $34 \mathrm{mmol} / \mathrm{L}$ $\mathrm{NaHCO}_{3}$ catholyte more than three times that in $17 \mathrm{mmol} / \mathrm{L} \mathrm{Na}_{2} \mathrm{SO}_{4}$ catholyte for that $\mathrm{HCO}_{3}{ }^{-}$was the most likely source of protons for adsorbed active hydrogen $\left(\mathrm{H}^{*}\right)$ in Pd active centers.
\end{abstract}

Keywords. Pd/Ni electrode, 2,4-dichlorophenoxyacetic acid, removal efficiency

\section{Introduction}

Chlorinated aromatic compounds in rivers, lakes and ground waters by pesticides are hazardous pollutants in the environment which have been listed as key pollutants by the U.S. Environmental Protection Agency for Toxicity to humans and organisms [1, 2]. They are present in effluents from agricultural activities because of its low price and good selectivity, 2,4-D is used to remove various weeds in crops [3]. However, 2,4-D is a kind of pollutant that is difficult to biodegrade, and it exists in rivers, lakes and ground waters, soil resources and agricultural products for a long time [4, 5]. Therefore, 2, 4-D is considered to be a pollutant harmful to public health, and it is necessary to study how to remove it.

Thus the reductive dechlorination treatment has become a research hotspot. In this dechlorination process, only the chlorine atom is selectively replaced by hydrogen, and the other structure of the reactant remains unchanged. The application of $\mathrm{Pd} / \mathrm{Ni}$ electrode

${ }^{1}$ Corresponding Author, C Y Lou, Zhejiang Light Industrial Product Inspection and Research Institute, Hangzhou 310018, People's Republic of China; E-mail: 149203760@qq.com. 
in reductive dechlorination faced same difficult problem such as the low current efficiency (CE) of dechlorination, the low removal efficiency, the large amount of precious metal palladium, the large power consumption, and so on [6]. In the present work the electrode studied by the group of Song [7], the removal efficiency of 2,4-D was as high as $98 \%$ and the maximum CE was $14 \%$ after 180 min dechlorination reaction controlled the current density of $1.5 \mathrm{~mA} / \mathrm{cm}^{2}$. The research group of $\mathrm{Xu}[6,8]$ researched the dechlorination of 2,4-D using nanosized TiN doped $\mathrm{Pd} / \mathrm{Ni}$ electrode achieved nearly $100 \%$ removal of $2,4-\mathrm{D}(0.226 \mathrm{mmol} / \mathrm{L})$ after $120 \mathrm{~min}$ dechlorination reaction controlled the current density of $1.667 \mathrm{~mA} / \mathrm{cm}^{2}$. A lot of work on electrode preparation have done by previous researchers in order to reduce energy consumption, improve dechlorination efficiency, and reduce palladium loading. But there are very little investigatory about the different electrolyte solutions impact on the dechlorination efficiency. In this study, trying to choose appropriate electrolyte solutions increase dechlorination efficiency at lower reduction potential and smaller palladium loading.

In this study, a novel electrolyte solution of $\mathrm{NaHCO}_{3}$ for the electrochemical reductive dechlorination of 2,4-D on palladium/nickel-foam $(\mathrm{Pd} / \mathrm{Ni})$ electrode was introduced. Contrast tests found that the dechlorination efficiency in $\mathrm{NaHCO}_{3}$ catholyte was much higher than in the $\mathrm{NaCl}, \mathrm{NaClO}_{4}$ or $\mathrm{Na}_{2} \mathrm{SO}_{4}$ catholyte which has achieved an unprecedented high dechlorination efficiency characterized by low energy consumption, the least Pd loading, the simplest electrode preparation process and the highest removal efficiency compared with previous researches $[7,8]$.

\section{Experimental}

\subsection{Chemical Reagent}

Palladium chloride $\left(\mathrm{PdCl}_{2} ; \geq 99.97 \%\right.$ ) were purchased from Aladdin Reagent Co., Ltd., China. Nafion-117membranes were purchased from Du Pont de Nemours \& Co., USA. All the other chemicals such as o-chlorophenoxyacetic acid (o-CPA), pchlorophenoxyaceticacid ( $p$-CPA), phenoxyaceticacid (PA) and so on were purchased from Huadong Medical Co., Ltd., China. Ultrapure water generated by a MilliporeMilliQ system with a specific conductivity $\geq 18.2 \mathrm{~m} \Omega / \mathrm{cm}$ was used all the experiments in the paper. Methanol (HPLC-grade) used as the fluidity of high performance liquid chromatography (HPLC) were bought from the Aladdin Reagent Co., Ltd., China.

\subsection{Electrode Preparation}

The cleaning method of the foamed nickel substrate (with the size of $20 \mathrm{~mm} \times 20 \mathrm{~mm} \times$ $1.2 \mathrm{~mm}$ ) (the pore density of $110 \mathrm{ppi}$ ) was described in the previously published paper [7]. $\mathrm{Pd} / \mathrm{Ni}$ electrode was prepared through the displacement reaction. Put the cleaned nickel foam into $40 \mathrm{~mL}$ of $0.5 \mathrm{mmol} / \mathrm{L} \mathrm{PdCl}_{2}$ and $34 \mathrm{mmol} / \mathrm{L} \mathrm{NaCl}$ aqueous solution, and then shook it in an oscillator at a unchanged temperature of $30^{\circ} \mathrm{C}$ and a unchanged speed of $160 \mathrm{rpm}$ for $90 \mathrm{~min}$ until the yellow reaction solution became colorless. Removed the $\mathrm{Pd} / \mathrm{Ni}$ electrode from the faded solution, wash it with ultrapure water three times and dry it with high-purity nitrogen, then it could be used for dechlorination experiments. The electrochemical dechlorination reaction is a three-electrode electrolysis system: counter electrode(platinum), working electrode $(\mathrm{Pd} / \mathrm{Ni})$ and reference electrode (saturated calomel electrode (SCE)), respectively. 


\subsection{Batch Experiments}

The 2,4-D reductive dechlorination experiments were carried out in a customized H-type cell located in an unchanged temperature water bath at the temperature of $25 \pm 0.1^{\circ} \mathrm{C}$. Htype cell consisted of cathode and anode with a volume capacity of $100 \mathrm{~mL}$ and $50 \mathrm{~mL}$, respectively. For every experiment, $30 \mathrm{~mL} \mathrm{NaHCO}_{3}(34 \mathrm{mmol} / \mathrm{L})$ and 2,4-D (0.226 $\mathrm{mmol} / \mathrm{L}$ ) catholyte was added to the cathodic cell, which was stirred with a magnetic bar; $25 \mathrm{ml} \mathrm{Na} \mathrm{SO}_{4}(17 \mathrm{mmol} / \mathrm{L})$ aqueous solution was added to the anode cell in order to provided a harmless electrolysis reaction $\left(\mathrm{H}_{2} \mathrm{O}-2 \mathrm{e} \rightarrow\left(1 / 2 \mathrm{O}_{2}\right)+2 \mathrm{H}^{+}\right)$. The comparative experiment of different catholyte were carried out, used the other three catholyte such as $\mathrm{NaCl}(34 \mathrm{mmol} / \mathrm{L}), \mathrm{NaClO}_{4}(34 \mathrm{mmol} / \mathrm{L})$ or $\mathrm{Na}_{2} \mathrm{SO}_{4}(17 \mathrm{mmol} / \mathrm{L})$ to replace $\mathrm{NaHCO}_{3}$ $(34 \mathrm{mmol} / \mathrm{L})$. The working and reference electrodes were immersed in the cathodic cell, and the counter electrode was placed in the anode cell. All electrochemical experiment potential values were relative to SCE in this paper. All constant potential dechlorination experiments were carried out at $-0.55 \mathrm{~V}$. Both the dechlorination experiments and the Linear sweep voltammetry experiment were carried out at $298 \pm 1 \mathrm{~K}$ using the CHI-660D electrochemical workstation made in $\mathrm{CH}$ Instruments, Inc. Each 2,4-D dechlorination experiment was reacted for $180 \mathrm{~min}$, and $0.4 \mathrm{~mL}$ samples were taken from the cathodic cell at a certain time intervals for HPLC testing.

\subsection{Analytical Methods}

The content of palladium in the displacement solution were analyzed by a inductively coupled plasma optical emission spectrometry (ICP-OES), optima 7000DV PerkinElmer Instruments Inc. The concentrations of reactants and products such as 2,4-D, oCPA, $p$-CPA and PA were detected by an HPLC, Agilent 1260 series instruments. Detailed detection methods and the calculation method of $\mathrm{CE}$ for the 2,4-D electrochemical reductive dechlorination could refer to [7].

\section{Results and Discussion}

\subsection{The Pd Loading on the Ni Electrode}

The palladium loading of $\mathrm{Pd} / \mathrm{Ni}$ electrode was detected by ICP-OES, and Pd loading on electrode was $2.02 \mathrm{mg}$. Divide the total amount of palladium loading by the total area of the two sides of the nickel foam electrode by $10 \mathrm{~cm}^{2}$, and $\mathrm{Pd}$ loading of the $\mathrm{Pd} / \mathrm{Ni}$ electrode was calculated to be $0.202 \mathrm{mg} / \mathrm{cm}^{2}$, which was much lower than that of $\mathrm{Pd} / \mathrm{Ni}$ electrode prepared by electrochemical pulse method $\left(0.668 \mathrm{mg} / \mathrm{cm}^{2}\right.$ and $3.4 \mathrm{mg} / \mathrm{cm}^{2}$, respectively) $[7,8]$. The electrodes have the least amount of noble metals and thus greatly reduced the cost of the electrode.

\subsection{The 2,4-D Removal Experiments in Different Catholyte by Pd/Ni Electrode}

The 2,4-D removal efficiency experiments were carried out on the $\mathrm{Pd} / \mathrm{Ni}$ electrode at constant potential of $-0.55 \mathrm{~V}$ in four different catholytes. In figure 1 , the concentration of 2,4-D decreased with the increasing dechlorination reaction time in four different catholyte, in particular displayed that 2,4-D was completed removed in the $\mathrm{NaHCO}_{3}$ catholyte after $180 \mathrm{~min}$ of reaction. At this time, only $74.8-55.6 \%$ of $2,4-\mathrm{D}$ were removed 
in the other catholyte. The enhanced electrochemical dechlorination effect of bicarbonate anion can be speculated from the experimental results.

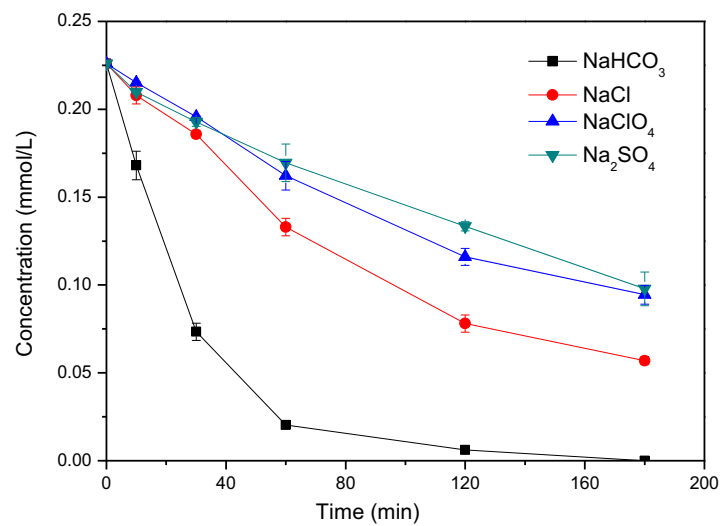

Figure 1. Time dependence of 2,4-D concentration in $34 \mathrm{mmol} / \mathrm{L} \mathrm{NaHCO}, 34 \mathrm{mmol} / \mathrm{L} \mathrm{NaCl}, 34 \mathrm{mmol} / \mathrm{L}$ $\mathrm{NaClO}_{4}, 17 \mathrm{mmol} / \mathrm{L} \mathrm{Na}_{2} \mathrm{SO}_{4}$ catholyte, respectively on $\mathrm{Pd} / \mathrm{Ni}$ electrode at constant potential of $-0.55 \mathrm{~V}$.

\subsection{Dechlorination Activity and Selectivity}

The changes in the amount of reactants, products and carbon mass with time during the reductive dechlorination of 2,4-D in $34 \mathrm{mmol} / \mathrm{L} \mathrm{NaHCO}_{3}, 34 \mathrm{mmol} / \mathrm{L} \mathrm{NaCl}, 34 \mathrm{mmol} / \mathrm{L}$ $\mathrm{NaClO}_{4}, 17 \mathrm{mmol} / \mathrm{L} \mathrm{Na}_{2} \mathrm{SO}_{4}$ catholyte respectively on the $\mathrm{Pd} / \mathrm{Ni}$ electrode were illustrated in figure 2. During the reaction, as the reaction time increased, the reactants continued to decrease, and the products of $p$-CPA, $o-\mathrm{CPA}$ and PA, were produced continuously. In addition, the total carbon content maintained at $94 \%-99 \%$, only a small amount of $p$-CPA produced, and the main product was PA. An obvious result of the concentration of $o$-CPA was always higher than that of $p$-CPA during the reductive dechlorination, which was consistent with the results of previous studies, interpreted as the chlorine atom located in the para-position of 2,4-D was easy to be substituted than it in the ortho-position by active hydrogen $\left(\mathrm{H}^{*}\right)$ as a function of the steric hindrance formed by the adjacent functional groups $\left(-\mathrm{OCH}_{2} \mathrm{COOH}\right)$ of 2,4-D [9-11].

In figure 3, In the four different catholytes, the reductive reaction of 2,4-D is a pseudo-first order kinetic model, which can be shown as equation (1).

$$
-\ln (\mathrm{Ct} / \mathrm{C} 0)=\mathrm{kt}+\mathrm{b}
$$

where $\mathrm{k}$ is the observed rate constant $\left(\mathrm{min}^{-1}\right)$; $\mathrm{t}$ is the reaction time (min); $\mathrm{b}$ is a constant, and $\mathrm{C}_{\mathrm{t}}$ and $\mathrm{C}_{0}$ are the 2,4-D concentrations $(\mathrm{mmol} / \mathrm{L})$ at times of $\mathrm{t}=\mathrm{t}$ and $\mathrm{t}=0$, respectively. The $\mathrm{k}$ was $0.1375 \mathrm{~min}^{-1}$ in $34 \mathrm{mmol} / \mathrm{L} \mathrm{NaHCO}_{3}$ catholyte much larger than in other three catholyte. The enhanced dechlorination effect in $34 \mathrm{mmol} / \mathrm{L} \mathrm{NaHCO}_{3}$ catholyte can be further proved by hydrogen evolution reaction (HER). As the LSV curves shown in figure 4, among the four electrolytes, the rate of HER was the fastest in $34 \mathrm{mmol} / \mathrm{L} \mathrm{NaHCO}_{3}$ electrolyte solution. For the HER is a side reaction in the dechlorination of 2,4-D. Although it was not sufficient to infer the dechlorination rate based on the HER rate, it could provide some insights about the dechlorination effect. The faster the HER rate, the more $\mathrm{H}^{*}$ was produced. The more production of $\mathrm{H}^{*}$ were considered to be a key factor for effective dechlorination treatment $[7,12,13]$. In the $\mathrm{NaHCO}_{3}$ electrolyte, the $\mathrm{HER}$ reaction was fastest, indicating the most $\mathrm{H}^{*}$ were 
produced for the dechlorination, which resulted to significantly improving the dechlorination efficiency of 2,4-D.
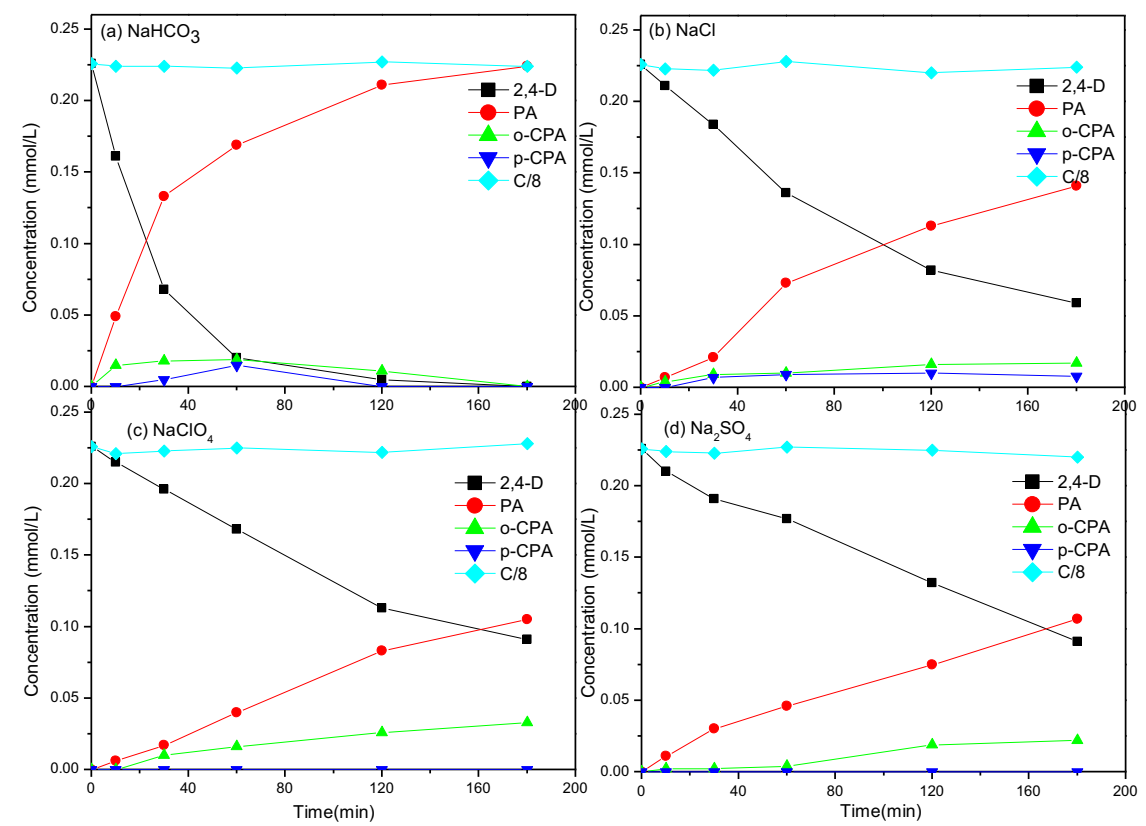

Figure 2. The changes in the amount of reactants, products and carbon mass with time in (a) $34 \mathrm{mmol} / \mathrm{L}$ $\mathrm{NaHCO}_{3}$, (b) $34 \mathrm{mmol} / \mathrm{L} \mathrm{NaCl}$, (c) $34 \mathrm{mmol} / \mathrm{L} \mathrm{NaClO}_{4}$ and (d) $17 \mathrm{mmol} / \mathrm{L} \mathrm{Na}_{2} \mathrm{SO}_{4}$ catholyte on Pd/Ni electrode at constant potential of $-0.55 \mathrm{~V}$.

\subsection{Enhanced Reductive Dechlorination Mechanism}

$\mathrm{CE}$ is closely related to the number of $\mathrm{H}^{*}$ consumed during the removal of 2,4-D. As displayed in figure 5 , with the reaction proceeded, the $\mathrm{CE}$ of reductive dechlorination of 2,4-D increased first and then decreased, the maximum $\mathrm{CE}$ value was $20.5 \%$ appeared in the reaction for $30 \mathrm{~min}$ in $34 \mathrm{mmol} / \mathrm{L} \mathrm{NaHCO}_{3}$. However, the maximum $\mathrm{CE}$ value was about $6.2-8.2 \%$ at $60 \mathrm{~min}$ in $34 \mathrm{mmol} / \mathrm{L} \mathrm{NaCl}, 34 \mathrm{mmol} / \mathrm{L} \mathrm{NaClO}_{4}, 17 \mathrm{mmol} / \mathrm{L} \mathrm{Na}_{2} \mathrm{SO}_{4}$ catholyte, respectively.

In the first 30 minutes, $\mathrm{H}^{*}$ was mainly used to reach the balance between the hydrogen in the metal hydride phase and the hydrogen in the solid solution phase; then, with the decrease concentration of 2,4-D would reduce the consumption of $\mathrm{H}^{*}$, which caused the CE to gradually decreased [14]. In the other three catholyte, the amount of $\mathrm{H}^{*}$ was relatively smaller, so the balance between the metal hydride phase and the solid solution phase arrived later, which could be explain by the CE value was smaller than that of in $\mathrm{NaHCO}_{3}$ catholyte, the maximum $\mathrm{CE}$ was obtained delayed at $60 \mathrm{~min}$. Therefore, it was appropriate to infer the 2,4-D removal efficiency improved by bicarbonate anion.

In figure 6 , the values of $\mathrm{pH}$ in the catholyte with time were carried out. The initial $\mathrm{pH}$ value was 3.95, due to the acidity of 2,4-D in $34 \mathrm{mmol} / \mathrm{L} \mathrm{NaCl}, 34 \mathrm{mmol} / \mathrm{L} \mathrm{NaClO}_{4}$ and $17 \mathrm{mmol} / \mathrm{L} \mathrm{Na}_{2} \mathrm{SO}_{4}$ catholyte. As the reaction proceeds, the $\mathrm{pH}$ rose rapidly in catholyte at the first $2 \mathrm{~min}$ and then slightly increased about 12.00. However, there was different result in $34 \mathrm{mmol} / \mathrm{LNaHCO}_{3}$ catholyte, the $\mathrm{pH}$ value was varied within 8.7610.02. A low $\mathrm{pH}$ value was favorable to dechlorination in previous studies [15]. So the 
accelerate dechlorination reaction maybe for bicarbonate anion can stabilize the $\mathrm{pH}$ in the $\mathrm{NaHCO}_{3}$ catholyte.
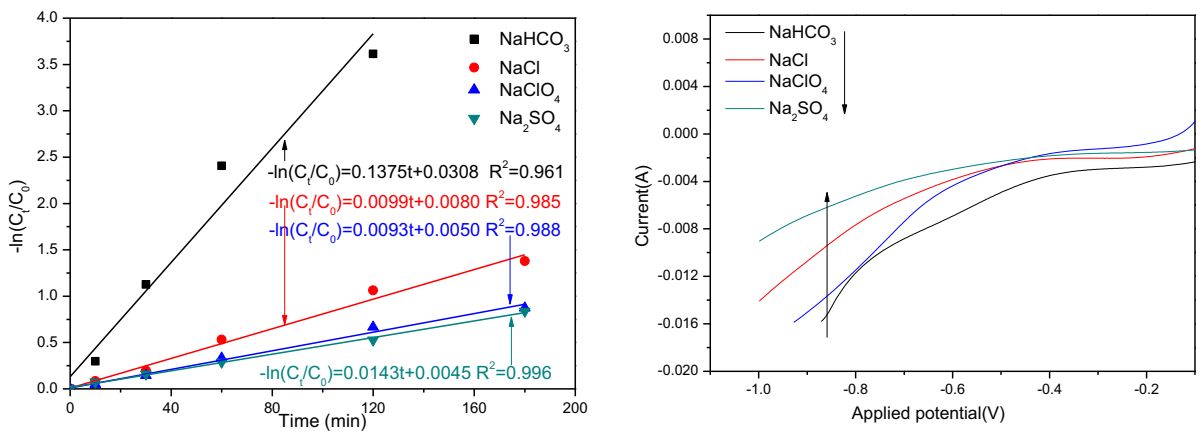

Figure 3. Rate constant of 2,4-D dechlorination in 34 Figure 4. Linear sweep voltammetry curves in 34 $\mathrm{mmol} / \mathrm{L} \mathrm{NaHCO} 3,34 \mathrm{mmol} / \mathrm{L} \mathrm{NaCl}, 34 \mathrm{mmol} / \mathrm{L}$ mmol/L $\mathrm{NaHCO}_{3}, 34 \mathrm{mmol} / \mathrm{L} \mathrm{NaCl}, 34 \mathrm{mmol} / \mathrm{L}$ $\mathrm{NaClO}_{4}$ and $17 \mathrm{mmol} / \mathrm{L} \mathrm{Na}_{2} \mathrm{SO}_{4}$ catholyte at constant $\mathrm{NaClO}_{4}$ and $17 \mathrm{mmol} / \mathrm{L} \mathrm{Na}_{2} \mathrm{SO}_{4}$ with $0.226 \mathrm{mmol} / \mathrm{L}$ potential of $-0.55 \mathrm{~V}$. 2,4-D electrolyte solution.
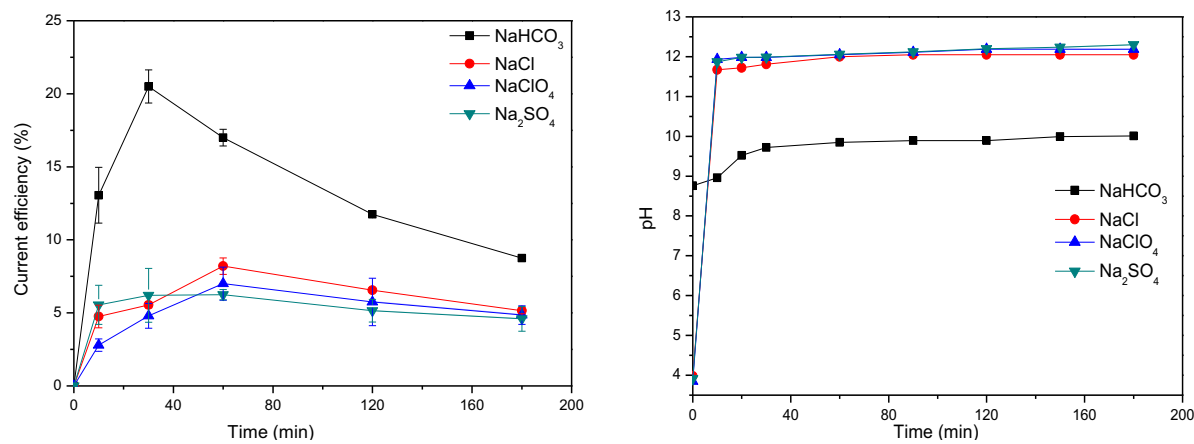

Figure 5. Current efficiency as functions of Figure 6. $\mathrm{pH}$ change as function of dechlorination time dechlorination time in $34 \mathrm{mmol} / \mathrm{L} \mathrm{NaHCO}, 34$ in $34 \mathrm{mmol} / \mathrm{L} \mathrm{NaHCO}, 34 \mathrm{mmol} / \mathrm{L} \mathrm{NaCl}, 34 \mathrm{mmol} / \mathrm{L}$ $\mathrm{mmol} / \mathrm{L} \mathrm{NaCl}, 34 \mathrm{mmol} / \mathrm{L} \mathrm{NaClO} 4,17 \mathrm{mmol} / \mathrm{L} \quad \mathrm{NaClO}_{4}, 17 \mathrm{mmol} / \mathrm{L} \mathrm{Na}_{2} \mathrm{SO}_{4}$ catholyte, respectively at $\mathrm{Na}_{2} \mathrm{SO}_{4}$ catholyte, respectively at constant potential of constant potential of $-0.55 \mathrm{~V}$. $-0.55 \mathrm{~V}$.

The overall reaction mechanism of electrochemical removal of 2,4-D on $\mathrm{Pd} / \mathrm{Ni}$ cathode had been researched in $[6,14,16]$. In this work, the reduction dechlorination mechanism may be inferred the following reaction pathways, which expressed in equations (2)-(5):

$$
\begin{gathered}
2 \mathrm{HCO}_{3}{ }^{-}+\mathrm{Pd}+2 \mathrm{e} \rightarrow 2 \mathrm{H}^{*}{ }_{\text {ads }} \mathrm{Pd}+\mathrm{CO}_{3}{ }^{2-} \\
\mathrm{M}-\mathrm{Cl}+\mathrm{AS} \leftrightarrow(\mathrm{M}-\mathrm{Cl})_{\text {ads }} \mathrm{AS} \\
(\mathrm{M}-\mathrm{Cl})_{\mathrm{ads}} \mathrm{AS}+\mathrm{e}^{-}+\left(\mathrm{H}^{*}{ }_{\text {ads }}\right) \mathrm{Pd} \rightarrow(\mathrm{M}-\mathrm{H})_{\mathrm{ads}} \mathrm{AS}+\mathrm{Cl}^{-}+\mathrm{Pd} \\
(\mathrm{M}-\mathrm{H})_{\mathrm{ads}} \mathrm{AS} \leftrightarrow \mathrm{M}-\mathrm{H}+\mathrm{AS}
\end{gathered}
$$

where $\mathrm{M}-\mathrm{Cl}$ are chlorinated reactants, $\mathrm{H}^{*}$ ads is adsorbed atomic, AS is the active sites on $\mathrm{Pd} / \mathrm{Ni}$ electrode. 


\section{Conclusions}

The different dechlorination efficiencies were compared in the four different cathode solutions for 2,4-D reduction with $\mathrm{Pd} / \mathrm{Ni}$ electrode manufacture by replacement deposition method. The 2,4-D was completed removed for no detectable by HPLC after $180 \mathrm{~min}$ of reaction in the $34 \mathrm{mmol} / \mathrm{L} \mathrm{NaHCO}_{3}$ catholyte on $\mathrm{Pd} / \mathrm{Ni}$ electrode at the constant potential of $-0.55 \mathrm{~V}$. The maximum $\mathrm{CE}$ of reductive dechlorination was $20.5 \%$ reached at $30 \mathrm{~min}$. The removal efficiency and the maximum $\mathrm{CE}$ in the $\mathrm{NaHCO}_{3}$ catholyte much larger than in the other catholytes. The experiments of enhanced reductive dechlorination mechanism indicated that more $\mathrm{H}^{*}$ were generated to participate the dechlorination reaction in $\mathrm{NaHCO}_{3}$ catholyte. This accelerated reaction mechanism and the application of dechlorination to other pollutants are for further study.

\section{References}

[1] Huang Y, Yang Q and Ao X L 2008 Scientometrics 77 177-86.

[2] Chen J L, Wang J Y, Wu C C and Chiang K Y 2011 Colloid. Surface. A 379 163-8.

[3] Ratti M, Canonica S, McNeill K, Bolotin J and Hofstetter T B 2015 Environ. Sci. Technol. 49 9797-806.

[4] Huang B B, Long J M, Chen W Q, Zhu Y Y, Zeng G M and Lei C 2016 Electrochim. Acta 208 195-201.

[5] Korshin G V and Jensen M D 2001 Electrochim. Acta 47 747-51.

[6] Sun C, Baig S A, Lou Z M, Zhu J, Wang Z X, Li X, Wu J H, Zhang Y F and Xu X H 2014 Appl. Catal. B-Environ. 158 38-47.

[7] He Z Q, Jian Q W, Tang J T, Xu T, Xu J L, Yu Z S, Chen J M and Song S 2016 Electrochim. Acta 222 488-98.

[8] Zhu K R, Baig S A, Xu J, Sheng T T and Xu X H 2012 Electrochim. Acta 69 389-96.

[9] Tsyganok A I and Otsuka K 1999 Appl. Catal. B-Environ. 22 15-26.

[10] Tsyganok A I 2006 Res. Chem. Intermediat. 32 357-72.

[11] Tsyganok A I and Otsuka K 1998 Electrochim. Acta 43 2589-96.

[12] Lou Z M, Zhou J S, Sun M, Xu J, Yang K L, Lv D, Zhao Y P and Xu X H 2018 Chem. Eng. J. 352 54957.

[13] Jiang G M, Lan M N, Zhang Z Y, Lv X S, Lou Z M, Xu X H, Dong F and Zhang S 2017 Environ. Sci. Technol. 51 7599-605.

[14] Sun C, Lou Z M, Liu Y, Fu R Q, Zhou X X, Zhang Z, Baig S A and Xu X H 2015 Chem. Eng. J. 281 183-91.

[15] Sun Z R, Wei X F, Hu X, Wang K and Shen H T 2012 Colloid. Surface. A 414 314-9.

[16] He Z Q, Tong Y W, Ni S L, Ye X C, Makwarimba C P, Huang X W, Zhang S H and Song S 2018 Electrochim. Acta 292 685-96. 